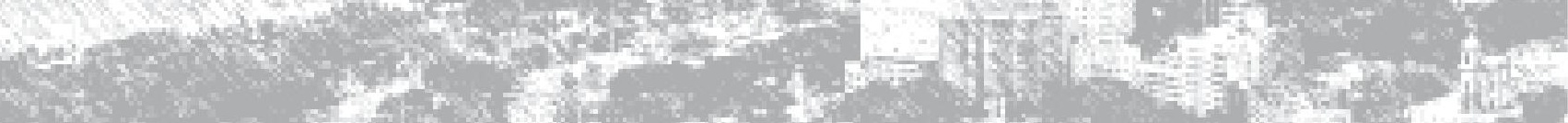

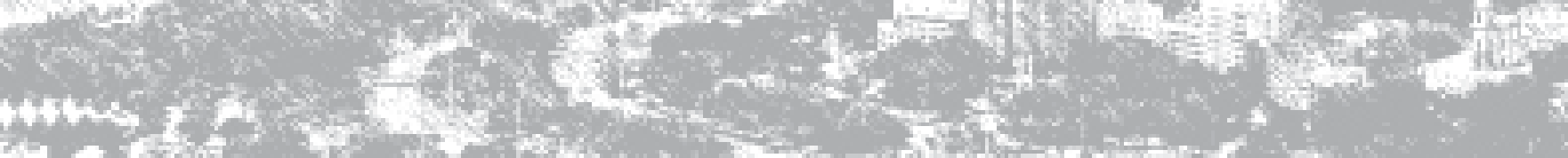

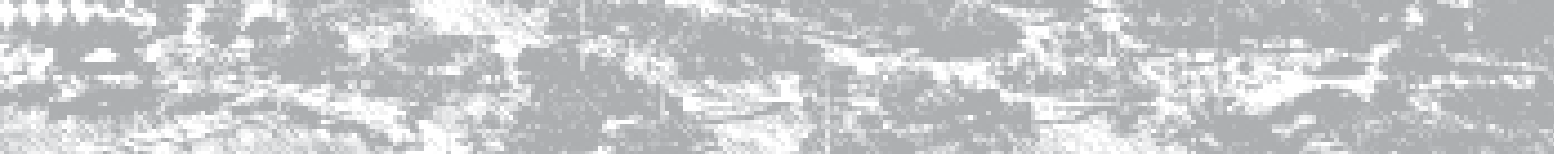

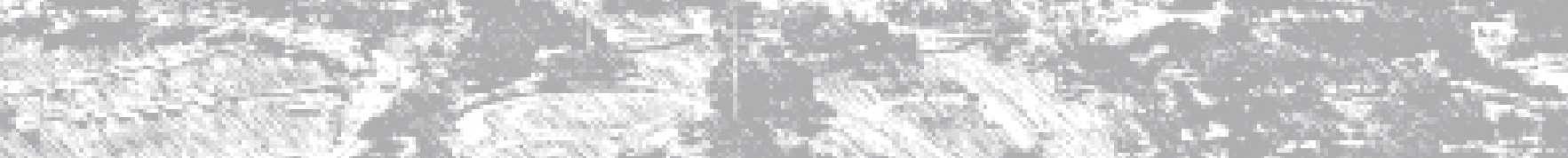
W.

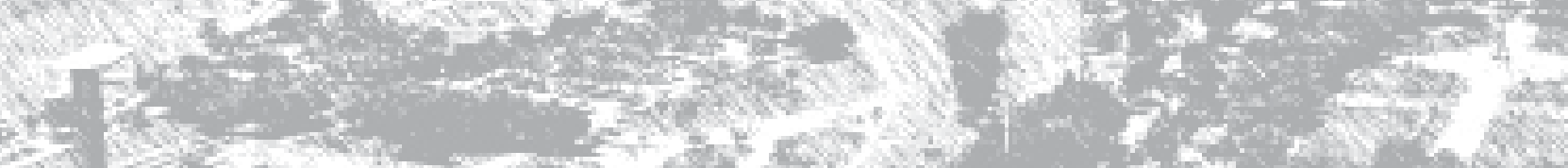

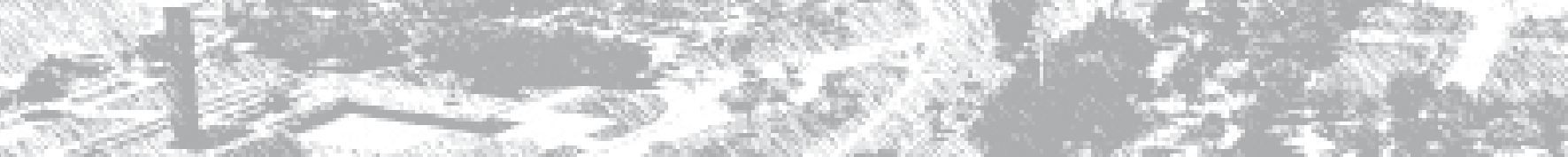

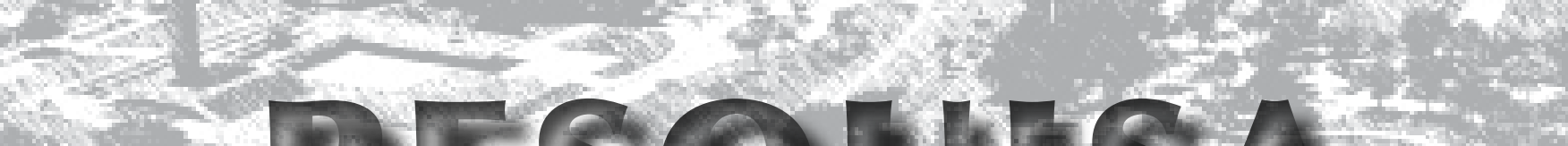

(I)

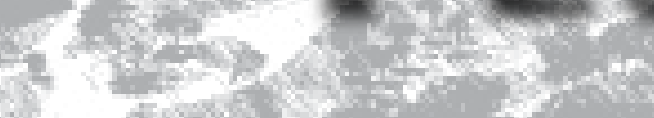

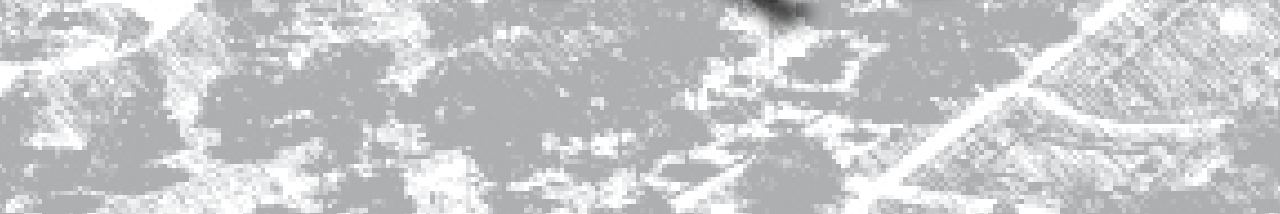

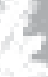
$-$

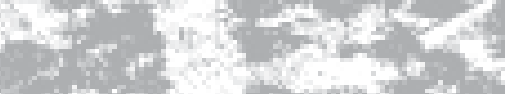

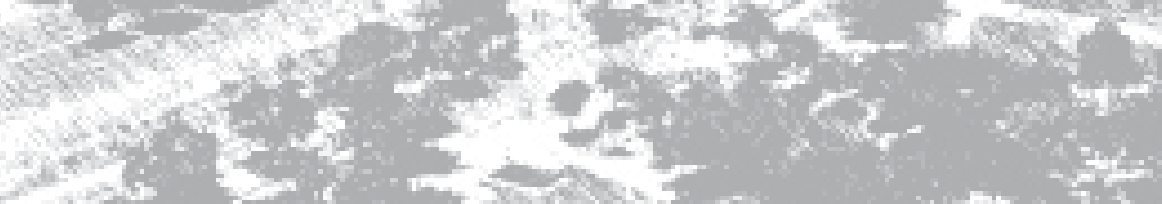

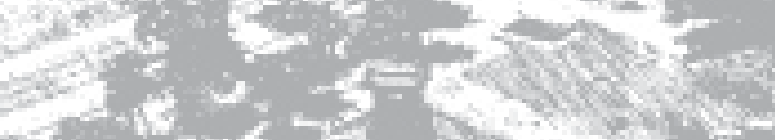

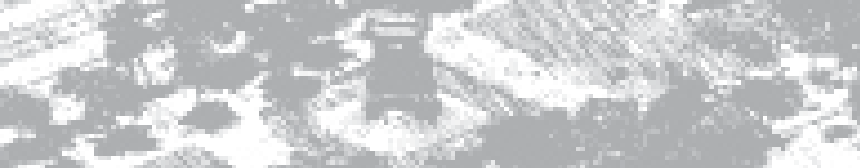
8 


\title{
ANÁLISE COMPARATIVA DA TRANSFORMAÇÃO E DA MORFOLOGIA DA PAISAGEM DE DOIS ESPAÇOS PÚBLICOS ADJACENTES: A PRAÇA PARIS E A ESPLANADA DO MONUMENTO AOS MORTOS DA SEGUNDA GUERRA MUNDIAL, NO BAIRRO DA GLÓRIA, RIO DE JANEIRO
}

\author{
COMPARATIVE ANALYSIS OF THE TRANSFORMATION AND MORPHOLOGY OF THE \\ LANDSCAPE OF TWO NEIGHBORING PUBLIC SPACES: PARIS SQUARE AND THE \\ ESPLANADE OF THE NATIONAL MONUMENT FOR THE DEAD SOLDIERS OF THE \\ SECOND WORLD WAR, IN RIO DE JANEIRO
}

Antônio Renato Guarino Lopes

Arquiteto e urbanista, professor na Universidade Estácio de Sá - PROARQ - Rio de Janeiro, e doutorando no Programa de Pós-Graduação em Arquitetura Faculdade de Arquitetura e Urbanismo - Universidade Federal do Rio de Janeiro.

e-mail:arguarino@ig.com.br

\section{Vera Regina Tângari}

Arquiteta, paisagista e urbanista, professora e pesquisadora da Faculdade de Arquitetura e Urbanismo - Universidade Federal do Rio de Janeiro.

e-mail:vtangari@uol.com.br

\section{RESUMO}

artigo visa analisar as analogias e diferenças existentes entre dois espaços públicos adjacentes, existentes no trecho de transição entre as zonas centro e sul do Rio de Janeiro, RJ: a praça Paris e a Esplanada do Monumento aos Mortos da Segunda Guerra Mundial, no bairro da Glória. $O$ artigo é iniciado por um breve histórico e uma análise formal de ambos os espaços, introduzindo ao seu foco principal: a análise da transformação e da morfologia da paisagem desses espaços, onde serão verificados aspectos da vegetação, volumetria construída e padrões de parcelamento do solo, tipologia, adensamento, as relações hierárquicas com a cidade, relações formais e funcionais com o entorno, aspectos ambientais, hierarquias internas, permeabilidade, distribuição e padrões de uso dos espaços.

Palavras-chave: Paisagem urbana, Rio de Janeiro, espaço público, análise morfológica.

\section{ABSTRACT}

The aim of the present article is to analyse differences and analogies between two neighboring public spaces existing in Gloria, a transitional neighborhood located between the center and the southern zone in Rio de Janeiro, RJ, Brazil. These spaces are Paris Square and the Esplanade of the National Monument for the Dead Soldiers of the Second World War. The article begins with a brief historical and a formal analysis of both spaces, wich introduces to the main focus of the work: the analysis of the transformation and the morphology of the landscape of these spaces, where vegetation, built volumetry, ground division patterns, typology, density, the hyerarchical relations with the city, formal and functional relations with the surroundings, environmental aspects, internal hyerarchies, permeability and functional distribution and patterns are verified.

Key words: Urban landscape, Rio de Janeiro, public space, morphological analysis. 


\section{INTRODUÇÃO}

Desde as últimas décadas do século 20 rejeita-se a idéia da cidade modernista, dividida espacialmente em setores que abrigam, quase exclusivamente, certos tipos de atividades. Hoje se abraça a idéia da cidade multifacetada, na qual a riqueza é dada por sua diversidade, mais que por uma ordenação a um padrão formal de determinado período histórico.

A falência dos modelos formais e estéticos modernistas de construção ou reurbanização de cidades abriu o campo para um novo olhar para a cidade. A sociedade e seu produto cultural passaram a serem vistos de modo mais abrangente.

É dentro dessa visão que a dicotomia estética existente entre dois espaços públicos urbanos se torna de interesse a uma análise. Esses dois espaços são a praça Paris e o Monumento aos Mortos da Segunda Guerra Mundial, ambos na Glória, região antiga que, embora próxima às áreas centrais da cidade, é considerada como um bairro da zona sul do Rio de Janeiro.

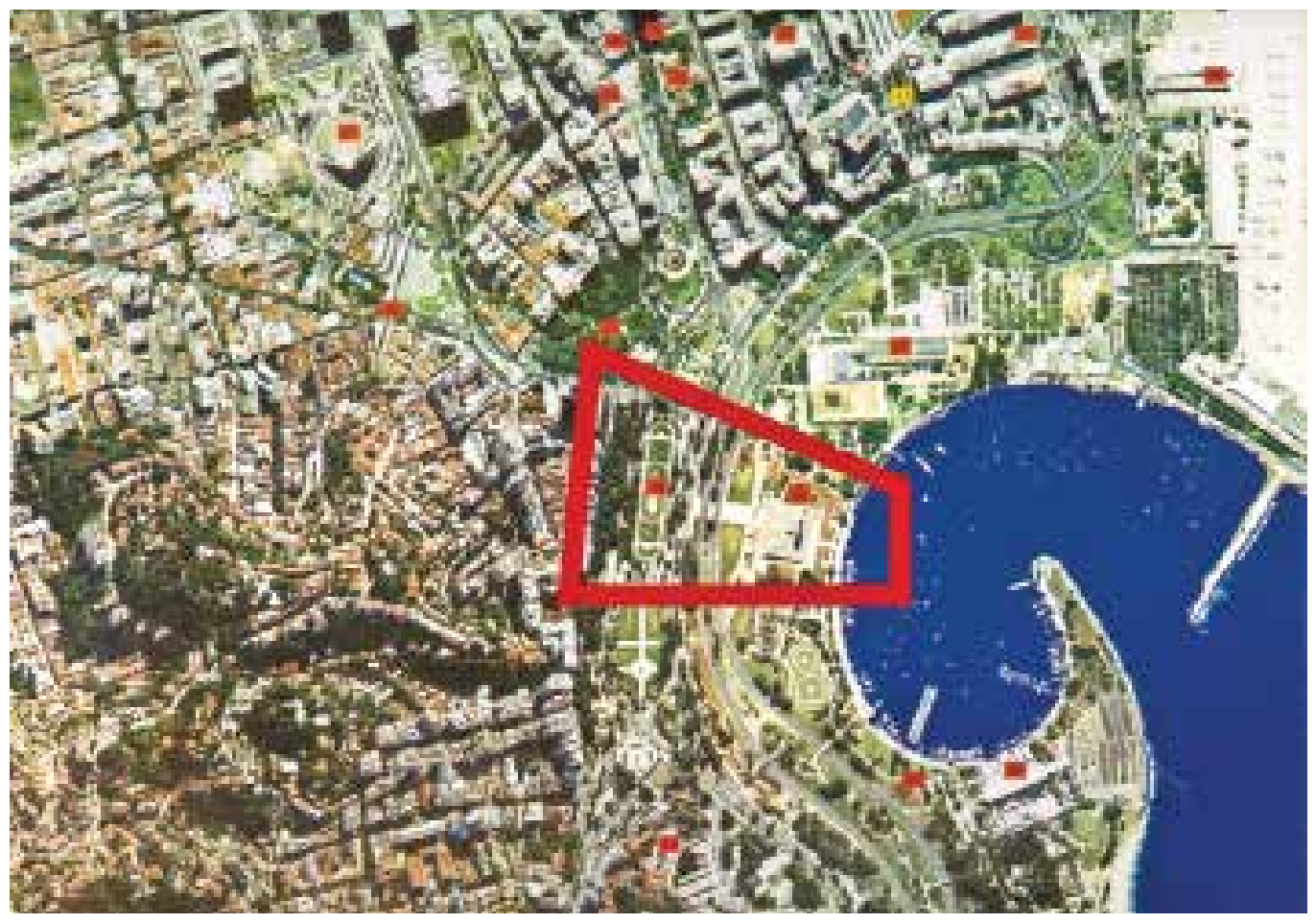

Figura 1: Planta de situação da área analisada em relação ao entorno

Fonte: Trecho extraído do Mapa de pontos do Rio de Janeiro. Rio de Janeiro: Prefeitura/Instituto Municipal de Urbanismo Pereira Passos, 1999

\section{HISTÓRICO URBANÍSTICO}

O primeiro aspecto que pode, de início, chamar a atenção para uma análise é a proximidade existente entre esses dois espaços (Figura 1); o trecho com o contorno demarcado corresponde aos dois espaços'). Reconhecida a freqüente escassez de 
espaços públicos urbanos, o que justificaria a existência desses dois exemplares em tal proximidade? A resposta pode ser obtida por uma análise histórica da evolução desse trecho da cidade.

A praça Paris (Figura 2) antecede, historicamente, o Monumento aos Mortos da Segunda Guerra Mundial. Foi inaugurada em 1929, tendo sido Arquimedes José da Silva, arquiteto do município, o autor do projeto. Essa praça constitui a única a ter sido construída dentre os espaços públicos idealizados pelo arquiteto francês Alfred Agache ${ }^{2}$ em seu plano para o Rio de Janeiro. A área sobre a qual se estende a praça Paris corresponde a trecho tomado ao mar e executado a partir do material proveniente do desmonte do Morro do Castelo ${ }^{3}$. O trecho seria plano e complementaria o espaço entre o já existente Passeio Público e o Outeiro da Glória.

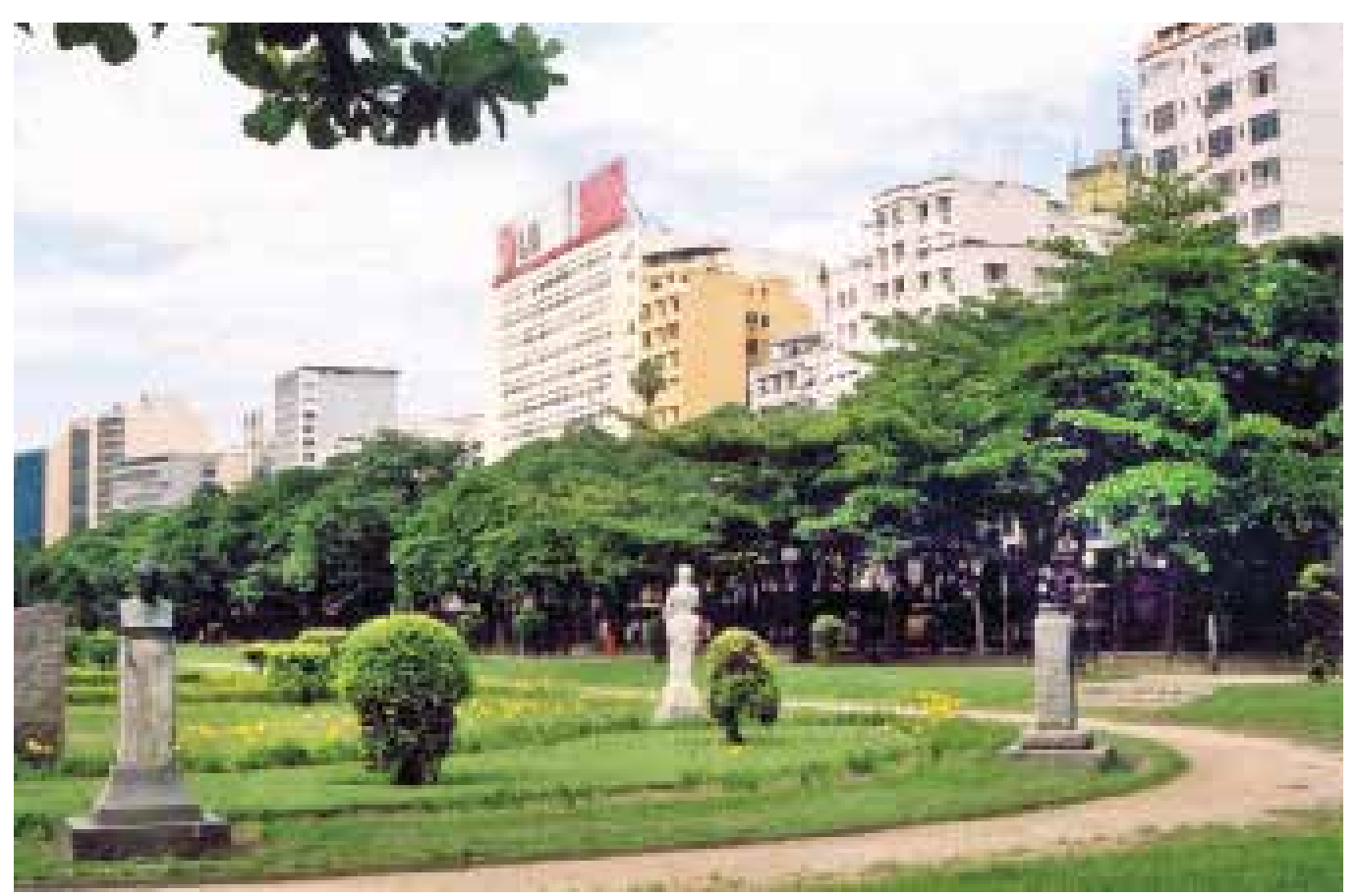

Figura 2: Vista interna da praça Paris

Crédito: Foto do autor

O Monumento aos Mortos da Segunda Guerra Mundial (Figura 3) também se dispõe sobre trecho tomado ao mar. O espaço ocupado por esse é parte do Aterro Glória-Flamengo 4, executado com o material do recente desmonte do morro de Santo Antônio. O Monumento corresponde à construção do projeto vencedor de concurso público realizado em 19565. Os autores, Hélio Ribas Marinho e Marcos Konder Netto, pertencem ao que se poderia chamar de uma terceira geração de arquitetos modernistas brasileiros, posterior à de Lúcio Costa e Oscar Niemeyer e outros6. Participaram como colaboradores nesse projeto Alfredo Ceschiatti (escultura em granito), Júlio Catelli Filho (escultura em metal) e Anísio Medeiros (painéis externos de azulejos e painel interno em pintura). 


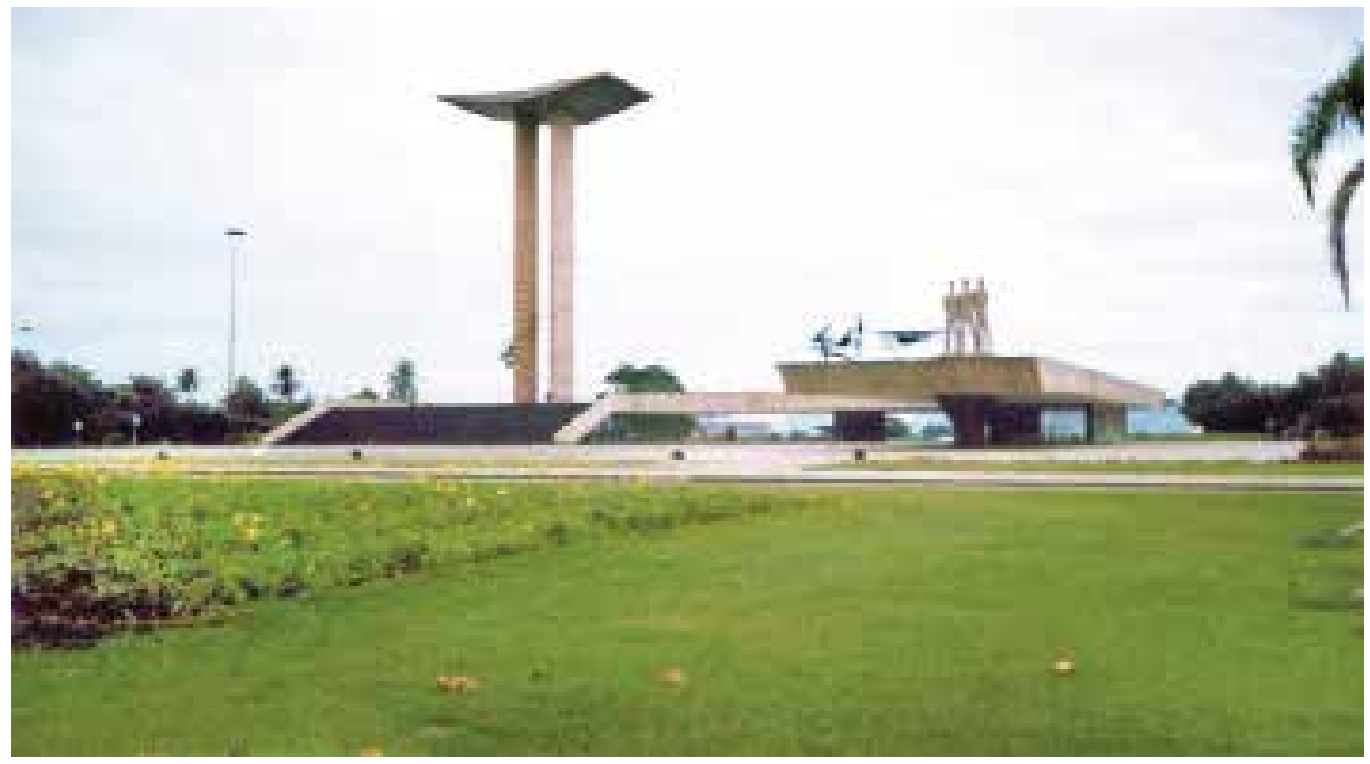

Figura 3: Vista da esplanada do Monumento aos Mortos da Segunda Guerra Mundial Crédito: Foto do autor

\section{ANÁLISE FORMAL}

A praça Paris pode ser considerada como um exemplar tardio do estilo eclético, que, no Rio de Janeiro, teve seu auge no início do século 20, principalmente com as obras de urbanização do prefeito Pereira Passos. Ainda que nos anos 20 alguns exemplares da arquitetura moderna já tivessem sido construídos em outros países, no Brasil houve até então poucas inserções pontuais, como as propostas de Gregori Warchavchik em São Paulo na segunda metade da década. Já se observava, no entanto, um direcionamento a uma arquitetura de caráter mais nacionalista, com a entrada em cena do Movimento Neocolonial7. A praça trazia, porém, características dos estilos de influência européia (Figura 4), no caso, a francesa. Dialogava, desse modo, com outros espaços públicos vizinhos a ela e existentes na época: a avenida Central (atual Rio Branco), de inspiração eclética, e o Passeio Público, o qual, embora seguisse padrões do jardim romântico do século 19, não apresentava desarmonia em relação à nova praça.

A fonte de inspiração da praça Paris ou outros exemplares congêneres é o jardim francês do século 17, principalmente os jardins de Versailles, mandados construir em 1667 por Luís XIV na França (com projeto de André Le Nôtre). Desse modo, várias características desse tipo de jardim são encontradas, ainda que em menor escala, na praça Paris.

Uma análise planimétrica aponta a forma da praça como fechada e geometricamente definida. Os subespaços gerados internamente à forma dada pelo contorno também são geometrizados, compondo um conjunto no qual se observam as noções de projeto e de autoria. Pela planimetria criam-se, assim, no interior da praça, duas áreas distintas, correspondentes a duas formas de contornos geométricos. 


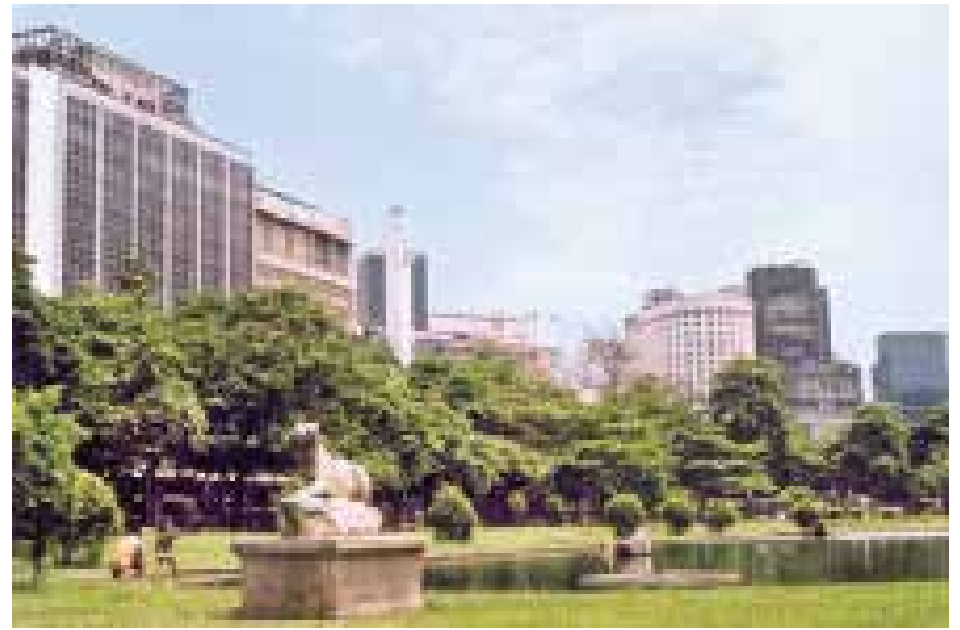

Figura 4 (esquerda): Vista interna da praça Paris com esculturas

Crédito: Foto do autor

Figura 5 (abaixo): Vista da praça Paris com pórtico do Monumento aos Mortos da Segunda Guerra Mundial ao fundo

Crédito: Foto do autor

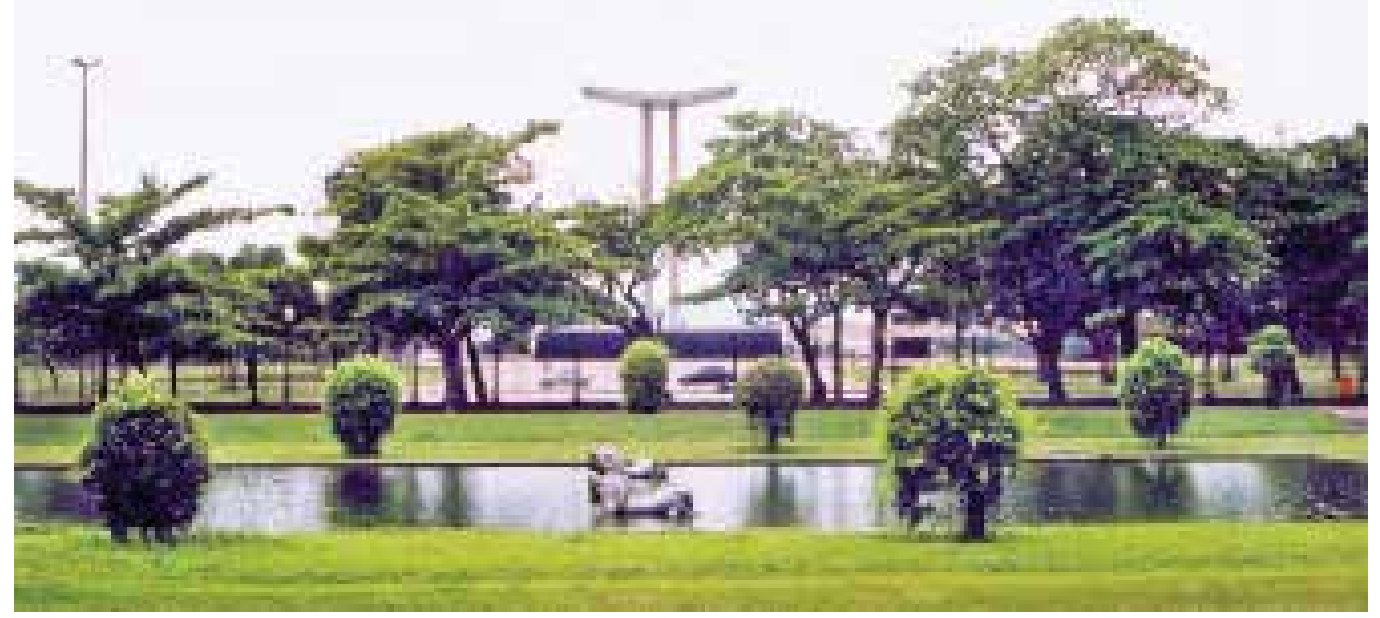

No sentido altimétrico se observa o mesmo sentido de organização formal, com claras definições entre alas de maior altura, outras de vegetação arbustiva (topiaria), além de trechos cobertos por espécies forrageiras.

O espaço é decomposto em linhas de força, que emprestam caráter ao lugar. No caso da praça Paris, é clara a intenção pela axialidade, a ocorrer no sentido longitudinal do terreno (Figura 5). No sentido transversal, são tomados dois eixos (passando centralmente em relação às duas áreas internas acima relacionadas).

A presença do espelho d'água com fonte indica a intenção de repetir, ainda que de forma modesta, a grandiosidade e os efeitos de movimento e sons das fontes d'água do modelo original francês. Do mesmo modo, encontram-se, dispostas em pontos focais de atenção, imagens em bronze sobre pedestais.

A nota dissonante surge apenas com a presença de um respiradouro do metrô, composto por formas geométricas modernistas. Executado em concreto armado aparente, $\mathrm{O}$ elemento foi implantado de modo a quase bloquear o trajeto dos usuários da praça. A guarita de segurança, junto da entrada principal (voltada para a avenida Augusto Severo) também se destaca formalmente por sua contemporaneidade de formas e materiais. 
Monumento aos Mortos da Segunda Guerra Mundial é representante de uma fase tardia do Modernismo brasileiro, em que os excessos formais vão sendo deixados de lado e as formas puras e volumes concisos tendem a prevalecer. Observa-se, no entanto, o uso da composição dinâmica, característico das obras inicias do Modernismo. O pórtico monumental, de 31 m de altura, atua como elemento vertical de contraste no conjunto, que se estende sempre seguindo a predominância horizontal, seja no nível térreo (uma esplanada quase totalmente livre, nos moldes dos espaços abertos modernistas), seja nos trechos com cotas positivas (grande plataforma no primeiro pavimento, apoiada em pequeno número de apoios) ou negativas (pavimento único no subsolo, que abriga o mausoléu). $\bigcirc$ nível térreo conta com poucos pontos de apoio da plataforma sobre o terreno. Alguns desses pontos servem como paredes (como as revestidas de painéis de azulejaria de Anísio Medeiros para a entrada ao mausoléu). O museu, também no nível térreo, conta com finos pilares em aço revestidos de alumínio entre os painéis em vidro transparente. A parede de fundo desse museu abriga outro painel, em pintura do mesmo artista plástico da azulejaria. $\bigcirc$ apoio central da parte da laje que se destaca à frente do conjunto é formado por uma interessante forma geométrica a qual concede leveza a um elemento surgido da necessidade estrutural. No nível superior foram implantadas tanto a escultura em granito de Alfredo Cheschiatti, a escultura metálica de Júlio Catelli Filho, além de um elemento escultórico revestido de granito (de menores dimensões e visível somente na própria plataforma suspensa). Ainda no nível térreo tem-se, na parte posterior do conjunto, um espelho d'água formado pelo escalonamento em diversos níveis até o nível do subsolo, de onde é também visível.

A incorporação das artes plásticas ao espaço arquitetônico, tão presente nesse projeto, é marca característica da produção brasileira do período. $\bigcirc$ monumento se impõe de forma inequívoca sobre a paisagem existente, ainda que a intenção projetual seja sempre a do respeito à visão panorâmica para a baía da Guanabara. É visto a partir de vários pontos do entorno: desde o bairro da Glória, o Aterro Glória-Flamengo, a avenida Rio Branco (formando, com esta, um eixo monumental ao modo do urbanismo haussmaniano) e a baía de Guanabara (Figura 6).

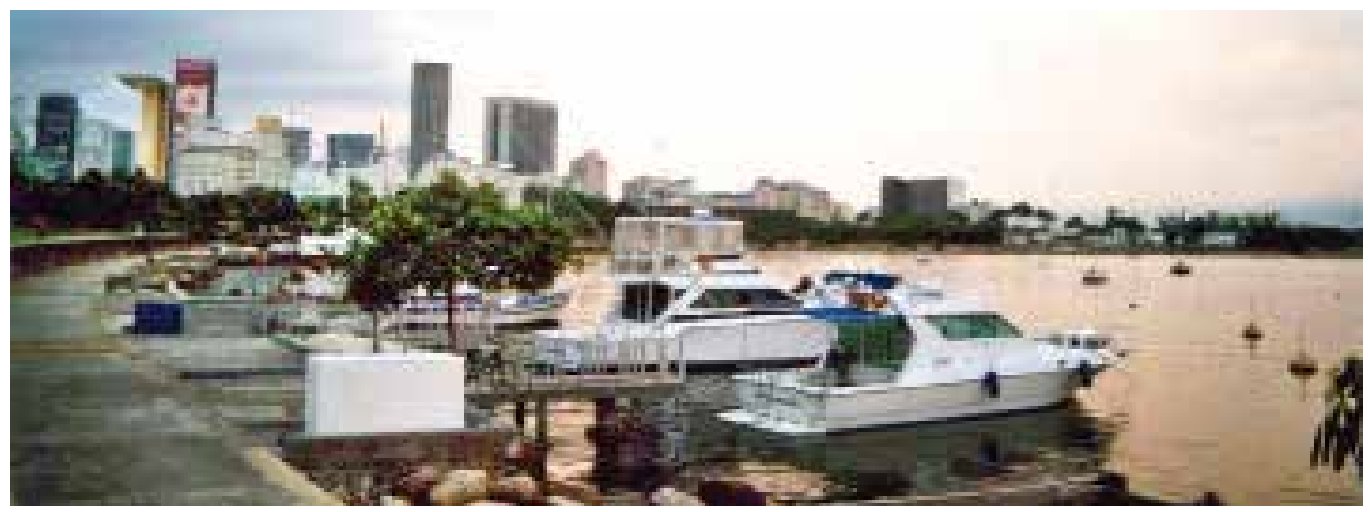

Figura 6: Vista da baía de Guanabara com o pórtico do Monumento aos Mortos da Segunda Guerra Mundial e os edifícios do centro da cidade ao fundo

Crédito: Foto do autor 
Ainda que os dois espaços partam da geometria e da regularidade de traçado, são quase opostos os efeitos de percepção desses espaços sobre o usuário. A praça Paris segue o ecletismo de feições beaux-arts, uma linguagem formal que já tinha sido destinada, e com sucesso, a outros espaços livres públicos e edifícios cariocas e retomava aspectos da tradição arquitetônica ocidental. $\bigcirc$ Monumento aos Pracinhas ${ }^{8}$ adota o Modernismo de meados do século 20, linguagem que, embora gozasse de prestígio popular e mesmo junto dos órgãos oficiais, parte do entendimento abstrato das noções da geometria e da economia quanto à variedade de texturas e materiais.

A racionalidade permeia ambos os projetos, mas levando a diferentes resultados. O primeiro espaço pretende, racionalmente, criar uma setorização entre pontos para a contemplação passiva e espaços para caminhadas ou brincadeiras, mas compreende como usuário o homem de um tempo dilatado, em que as horas transcorriam mais lentamente.

O segundo é pensado para o homem da idealizada modernidade que se pretendia implantar no Brasil. O Monumento, projetado para abrigar o afluxo de uma população crescente e carente de espaços destinados a comemorações cívicas, deveria também ser contemplado pelo apressado homem que passa em seu carro na velocidade do novo tempo da modernidade.

\section{ANÁLISE MORFOLÓGICA}

\section{Metodologia}

Adota-se como metodologia para o estudo dos espaços livres acima citados a análise morfológica. É importante ressaltar que a morfologia9, entendida de modo mais abrangente como o estudo das formas em seus aspectos externos, pode ser aplicada a vários campos do conhecimento. Será abordada aqui a análise morfológica aplicada aos espaços físicos, e, mais especificamente, aos espaços livres urbanos, relacionados tanto com elementos naturais quanto com elementos da cultura material humana. Mas a análise morfológica não se resume apenas à abordagem da conformação externa de um objeto de estudo - interessam-lhe também as origens causadoras de determinada forma. É, portanto, abordagem inclusiva, que incorpora saberes da geografia social, da história, da cultura, da antropologia. A paisagem será, portanto, vista aqui como fruto de processo cultural em evolução.

A análise será procedida pela interpretação de mapas que evidenciam a condição dos espaços estudados. Serão estudados:

- A estrutura morfológica básica, vegetação, volumetria construída e padrões de parcelamento do solo, tipologia e adensamento;

- as relações hierárquicas, formais e funcionais com o entorno, os aspectos ambientais;

- as hierarquias internas, permeabilidade, distribuição e padrões de uso dos espaços.

Vale salientar que as bases cartográficas utilizadas para essa análise são oficiais, obtidas em órgãos públicos. Pesquisaram-se tanto mapas recentes, os quais forneceram 
dados atualizados, necessários para a análise da situação do momento, quanto publicações e mapas antigos, que possibilitaram o conhecimento das transformações do espaço ao longo da história. Esse material consultado e recolhido foi complementado por visitas ao local, onde se realizaram o levantamento fotográfico e breves entrevistas relativas a determinados aspectos de interesse.

\section{Estrutura morfológica básica: vegetação, volumetria construída e padrões de parcelamento do solo, tipologia e adensamento}

O primeiro item de análise, que parte do suporte físico, levou às pesquisas cartográfica e histórica da área objeto de estudo. Conforme exposto no histórico relatado acima, a área sofreu, ao longo do século 20 , dois grandes aterros que the modificaram as características originais. A partir de um trecho caracterizado pela proximidade entre o mar e estratos de cotas mais altas (o morro de Santa Teresa) surgiu uma extensão plana - primeiramente com a criação da praça Paris e, posteriormente, com a urbanização da orla marítima entre o centro da cidade e a praia de Botafogo (Figura 7).

Os dois espaços livres - praça Paris e Esplanada do Monumento aos Mortos da Segunda Guerra Mundial - são, portanto, produtos culturais antes mesmo de sua urbanização: foi a vontade do homem que os criou. Se, analisados pela ótica da "teoria das persistências", de Poète e Lavedan ${ }^{10}$, os espaços aqui analisados são, em princípio, problemáticos (mesmo se levando em conta o suporte físico), pois teriam, necessariamente, de forjar, ao longo do tempo, sua própria influência enquanto espaço físico urbano. Quando se pensa que vários dos habitantes cariocas de hoje presenciaram as obras de urbanização durante o século passado, pode-se questionar sobre o sentido de pertencimento existente entre os habitantes e esses espaços.

Ainda relativamente ao suporte físico, observa-se que o trecho correspondente à praça Paris, por estar geograficamente resguardado pelo Outeiro da Glória e um equipamento de lazer urbano há mais tempo consolidado, o Passeio Público, fez-se como pertencente ao bairro da Glória, o qual, de certa forma, acolheu-os. O trecho do Monumento aos Pracinhas, por seu turno, tem relação formal mais predominante com as áreas do parque adjacentes a ele (os jardins junto do Museu de Arte Moderna, a pista para aeromodelismo e o trecho com a ciclovia junto do mar). A ruptura causada pelas pistas de grande velocidade do parque do Flamengo influencia grandemente no descolamento perceptivo do trecho do Monumento em relação à praça Paris e, principalmente, em relação ao bairro da Glória. Observe-se, no entanto, que havia, no projeto de urbanização do Aterro Glória-Flamengo, a previsão de uma passagem subterrânea entre o Monumento aos Pracinhas e os trechos mais internos da área aqui analisada. Tal passagem não foi construída" ${ }^{11}$.

A vegetação é também um elemento a reforçar a diferença de percepção que pode ser sentida entre esses dois espaços. Na área compreendida pelo Monumento aos Pracinhas o paisagismo prevê uma pequena interferência de elementos arbóreos junto da visada ao Monumento. É esse o protagonista do espaço; sua arquitetura modernista 


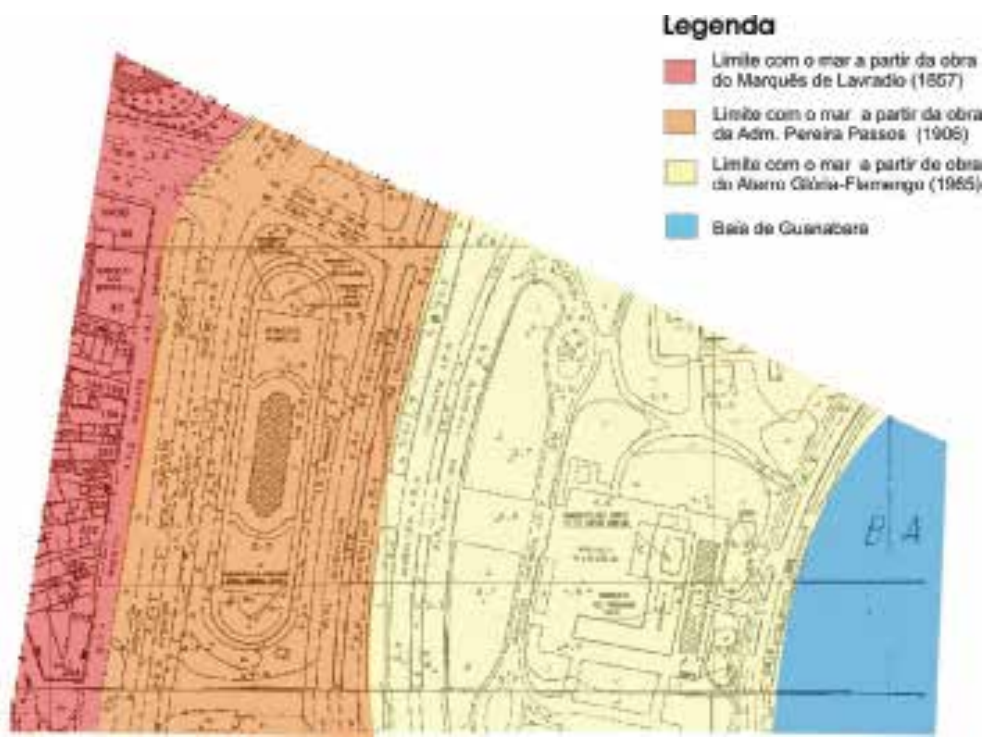

Figura 7: Mapa de suporte físico, realizado sobre Levantamento Aerofotogramétrico do Rio de Janeiro, fls. 287-B-III-5 e 287-D-I-2

Fonte: Instituto Municipal de Urbanismo Pereira Passos Prefeitura da cidade do Rio de Janeiro, 1999

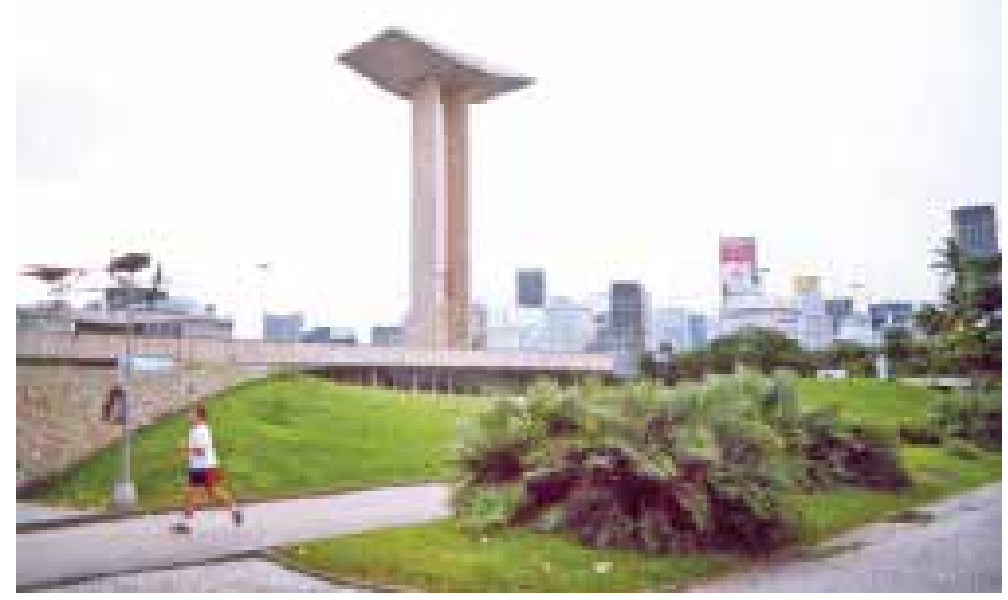

Figura 8: Vista posterior do Monumento aos Mortos da Segunda Guerra Mundial com ciclovia em primeiro plano e edifícios do centro da cidade ao fundo Crédito: Foto do autor

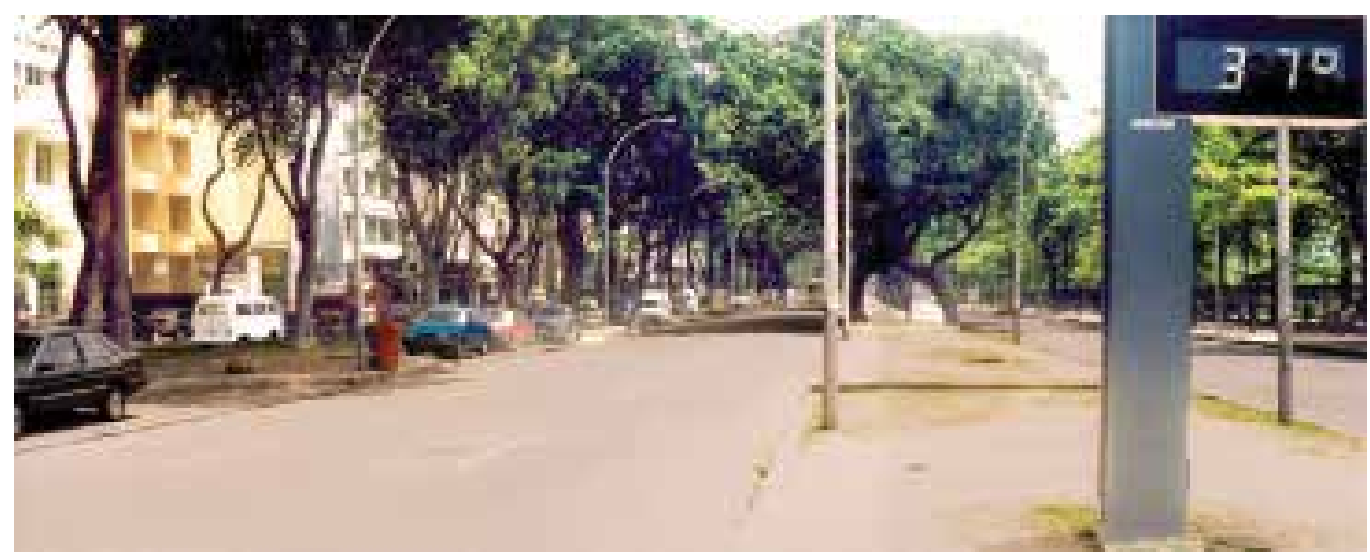

Figura 10: Cobertura vegetal nos espaços livres públicos, realizado sobre Levantamento Aerofotogramétrico do Rio de Janeiro, fls. 287-B-III-5 e 287-D-I-2

Fonte: Instituto Municipal de Urbanismo Pereira Passos - Prefeitura da cidade do Rio de Janeiro, 1999 
deve se impor de modo inequívoco sobre a paisagem do entorno. As árvores são, assim, de pequeno porte e predominam longos trechos gramados que oferecem um contraponto de cor, textura e vivacidade em vista do aspecto um tanto árido da esplanada.

A praça Paris apresenta, em seu interior, a predominância de gramíneas, com inserções pontuais da topiaria de influência francesa em pequenos arbustos a comporem uma planta formada por linhas de força geometrizadas. Em todo o contorno da praça vêem-se amendoeiras com dimensões consideráveis. Deve-se atentar para a aléia formada por árvores altas e frondosas, que criam um espaço de diferente percepção ao longo da avenida Augusto Severo. Essas árvores dispostas regularmente ao longo da via definem, com seus volumes e sua sombra, um trecho de diferente luminosidade e sensação de limite vertical, que contrasta com o caráter aberto do restante da área.

Em relação à volumetria construída, confirma-se o aspecto singular desses dois espaços: a praça Paris não é proveniente de um adro de igreja, como sucede com grande número das praças tradicionais brasileiras. Desse modo, não se encontra, na praça, nenhuma edificação de maior importância que carregue consigo a noção rossiana de monumento. Os lotes edificados lindeiros à praça (na avenida Augusto Severo) são ocupados por construções que seguem um padrão relativamente homogêneo, tanto no sentido da volumetria quanto no sentido de suas épocas de construção. A maioria das edificações apresenta altura superior a dez pavimentos e, segundo se observa por uma análise formal, foi construída posteriormente à inauguração da praça (prédios modernistas ou de um art déco típico das décadas de 30 e 40 no Rio de Janeiro ${ }^{12}$ ). Há também três edifícios com cerca de oito pavimentos. As exceções (tanto na avenida Augusto Severo quanto em alguns lotes nas ruas transversais a essa) correspondem a edifícios de dois pavimentos com arquitetura eclética, do início do século 20 , com suas
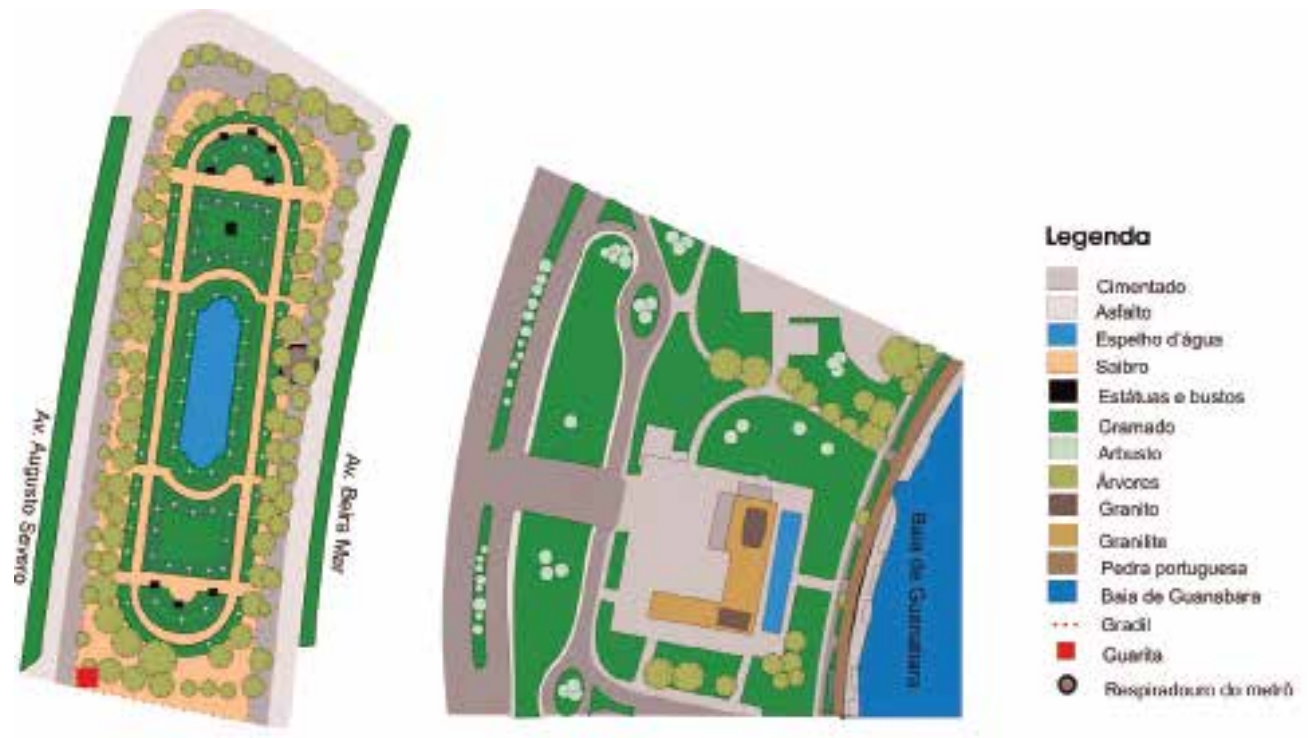

Figura 10: Cobertura vegetal nos espaços livres públicos, realizado sobre Levantamento Aerofotogramétrico do Rio de Janeiro, fls. 287-B-III-5 e 287-D-I-2

Fonte: Instituto Municipal de Urbanismo Pereira Passos - Prefeitura da cidade do Rio de Janeiro, 1999 
datas de construção gravadas em estuque em suas fachadas ${ }^{13}$, além de outros três lotes ocupados por duas oficinas mecânicas e um estacionamento de veículos. No interior da praça são muito poucos os elementos construídos: uma guarita de segurança e um respiradouro do metrô.

O trecho do Monumento aos Pracinhas também demonstra sua singularidade no sentido de sua relação volumétrica com o entorno: os edifícios mais próximos não são os conformadores da esplanada; ela se define efetivamente por seu paisagismo, por meio da relação de seu desenho com os desenhos dos outros espaços vizinhos e pertencentes ao Aterro Glória-Flamengo. A volumetria na esplanada se apresenta por meio do próprio monumento, contando com uma grande laje praticamente suspensa (no nível do primeiro pavimento e, por isso, deve ser considerada como elemento de volumetria marcante), esculturas monumentais sobre essa laje, e grande pórtico, formado por dois pilares longos e robustos encimados por uma laje de leve concavidade em direção ao alto ${ }^{14}$. Torna-se quase desnecessário comentar sobre o destaque que esse conjunto exerce sobre o entorno. Além dessa grande laje, existe, junto do estacionamento descoberto, uma pequena guarita de segurança.

Entre os dois espaços observam-se grandes diferenças quanto à volumetria: enquanto a praça Paris se encontra definida e espacialmente protegida em um de seus lados pelos edifícios junto dela, a esplanada do monumento demarca seus limites somente ao pedestre que circula nos trechos pavimentados e fixa, mentalmente, os limites daquele trecho em relação ao restante do Aterro. $O$ adensamento de toda essa área acontece praticamente somente no trecho dos edifícios da avenida Augusto Severo, com o contraponto em um pavimento formado pela laje do Monumento aos Pracinhas.

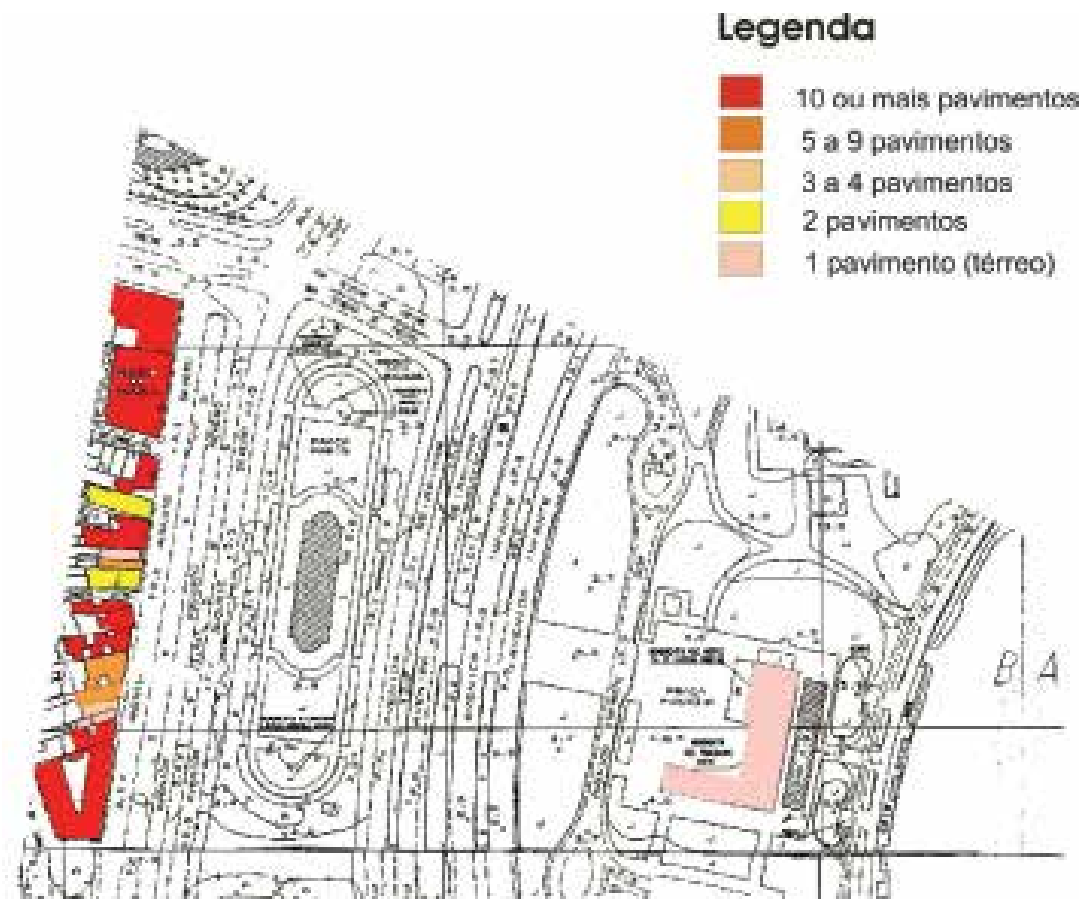

Figura 17: Mapa de volumetria construída, realizado sobre Levantamento Aerofotogramétrico do Rio de Janeiro, fls. 287-B-III-5 e 287-D-I-2 Fonte: Instituto Municipal de Urbanismo Pereira Passos - Prefeitura da cidade do Rio de Janeiro, 1999 


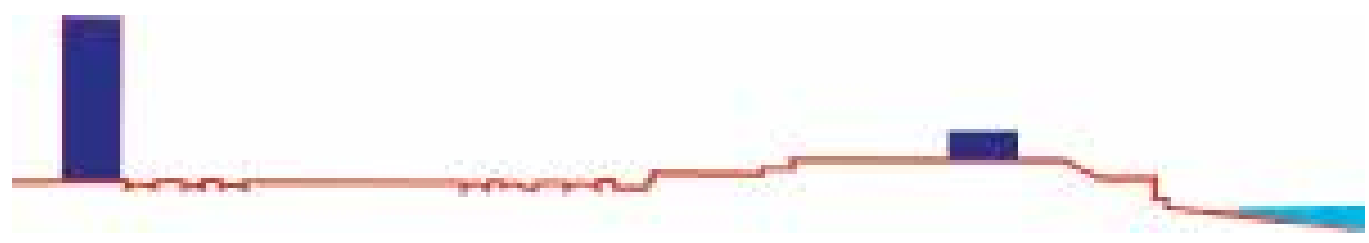

Figura 12: Corte esquemático do terreno Crédito: Desenho do autor

Quanto aos padrões de parcelamento de solo, é observável, pelos lotes remanescentes, o padrão típico carioca do lote de testada estreita e dimensões laterais que the conferem aspecto de profundidade. As testadas de maiores dimensões correspondem a remembramentos de antigos lotes que hoje sediam os edifícios mais recentes da avenida Augusto Severo. Entre esses, alguns, embora altos, seguem a tipologia da edificação junto da divisa do terreno. Outros, como o edifício do $\mathrm{IHGB}^{15}$, respeitam o padrão proposto por Agache (ver Nota 1 acima), definindo, na calçada, áreas cobertas com pilotis de grandes dimensões que sustentam o edifício acima. Há, portanto, influência do parcelamento do solo sobre a volumetria construída: aos lotes maiores, frutos de remembramentos, correspondem, em sua maioria, aos edifícios de maior cota de altura. $O$ aproveitamento desses terrenos segue, por sua vez, as possibilidades máximas permitidas nas leis de uso e ocupação do solo. Visto o alto valor imobiliário dos terrenos da zona sul carioca, em

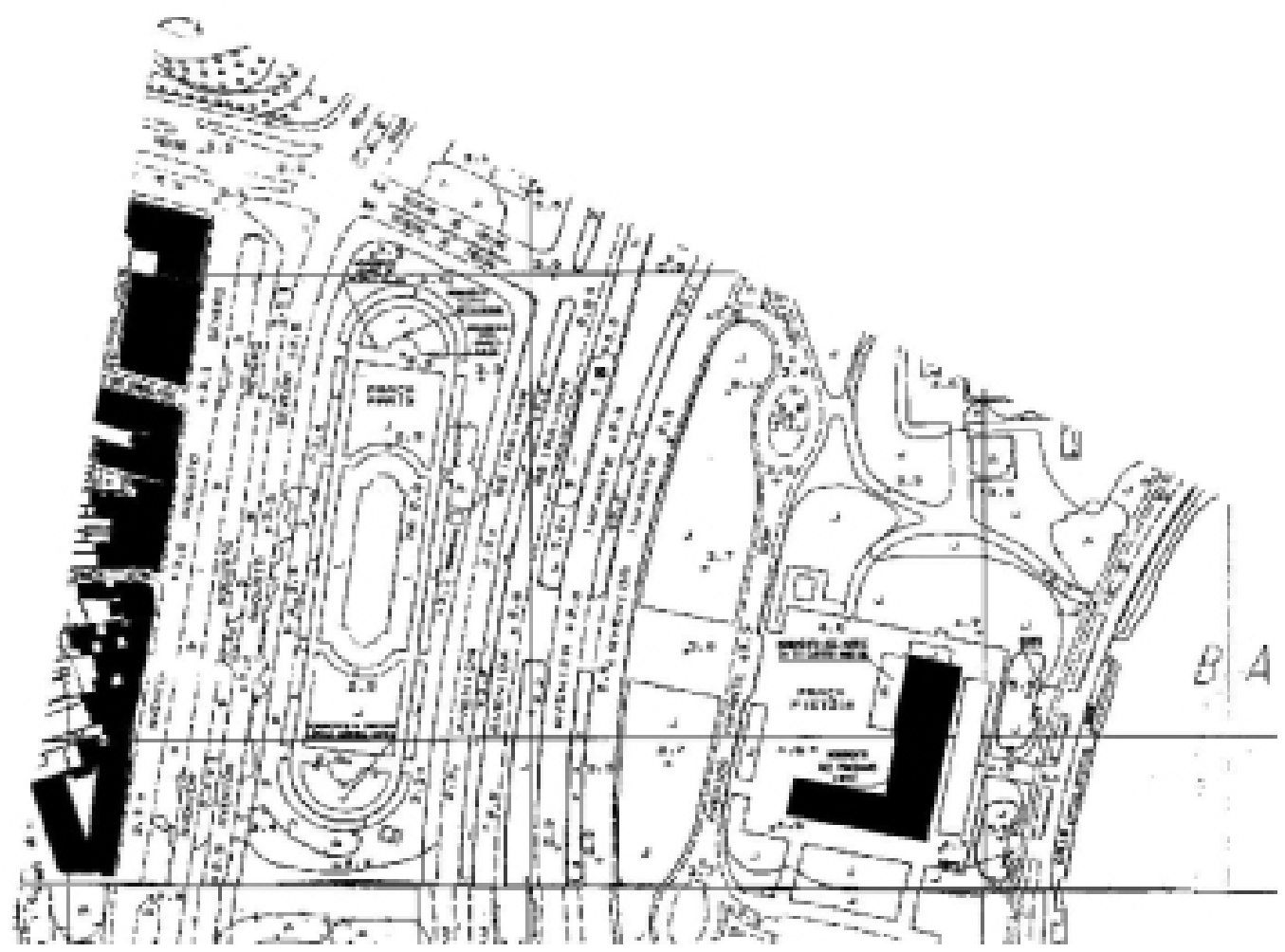

Figura 13: Mapa de adensamento, realizado sobre Levantamento Aerofotogramétrico do Rio de Janeiro, fls. 287-B-III-5 e 287-D-I-2

Fonte: Instituto Municipal de Urbanismo Pereira Passos - Prefeitura da cidade do Rio de Janeiro, 1999 


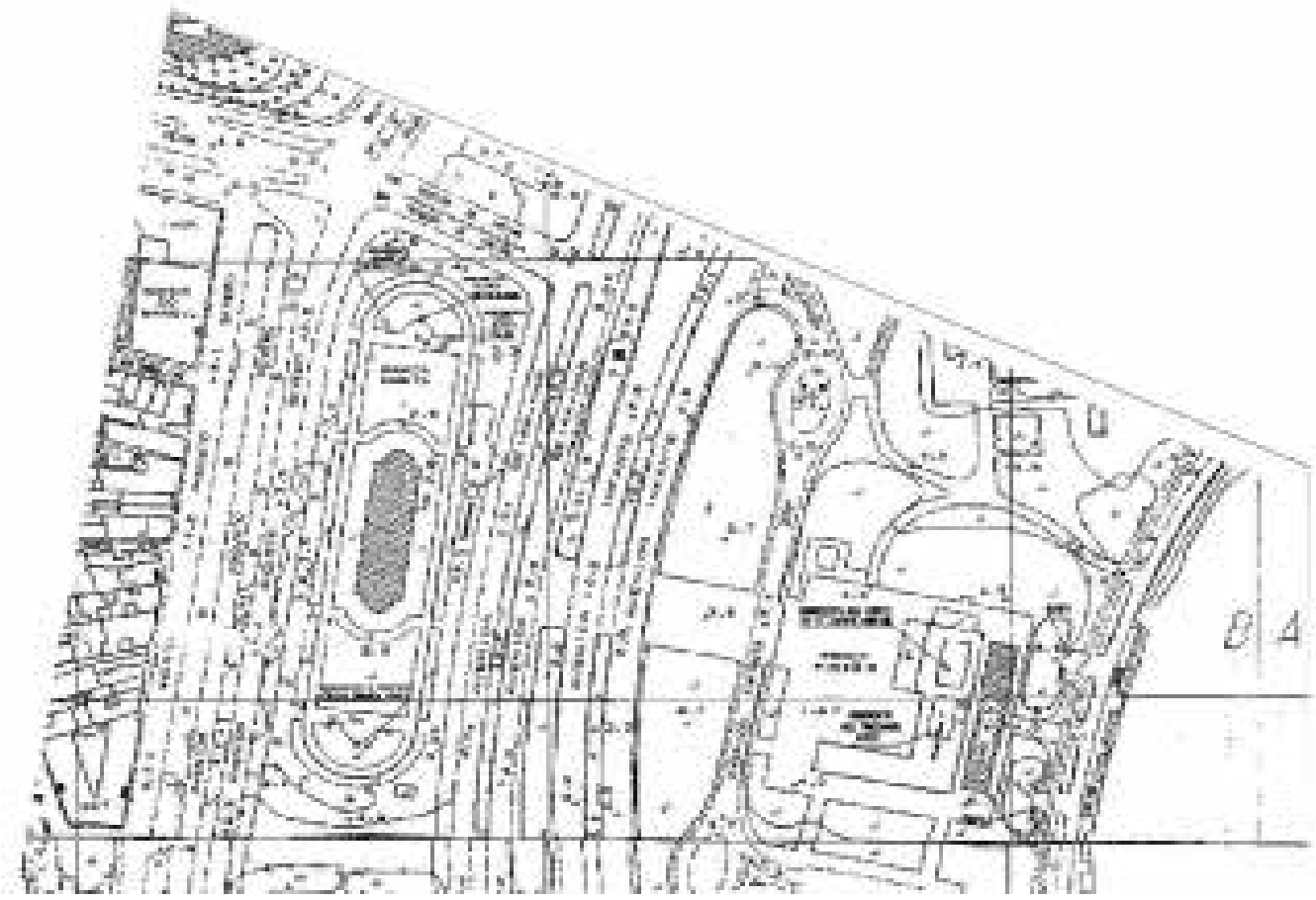

Figura 14: Mapa de padrões de parcelamento, realizado sobre Levantamento Aerofotogramétrico do Rio de Janeiro, fls. 287-B-III-5 e 287-D-I-2

Fonte: Instituto Municipal de Urbanismo Pereira Passos - Prefeitura da cidade do Rio de Janeiro, 1999

especial lotes junto da orla, a ocupação dos terrenos segue normalmente um padrão de aproveitamento máximo da taxa de ocupação permitida para os lotes.

\section{Relações hierárquicas, formais e funcionais com o entorno, os aspectos ambientais}

O trecho em análise é de rara predominância de espaços livres públicos e áreas ajardinadas sobre o elemento construído privado. Quanto ao nível hierárquico dos dois espaços em relação à cidade, a praça Paris deve ser considerada de importância de bairro, tendendo à municipal, uma vez que a maioria de seus usuários de freqüência mais regular é formada por moradores da vizinhança. No entanto, sua beleza e localização privilegiada atraem visitantes esporádicos de outras áreas ${ }^{16}$. O memorial de projeto do Monumento aos Pracinhas indica claramente que ele foi concebido para ser um monumento nacional, tanto servindo como espaço de homenagem aos soldados mortos, na Segunda Grande Guerra, como local para a realização de celebrações e atividades cívicas ou religiosas ${ }^{17}$. Além desses eventos em que se reúne grande número de pessoas, o monumento conta com freqüente visitação de turistas nacionais e estrangeiros. Sua localização em uma cidade de grande importância e visitação por parte de turistas, sua situação em relação à cidade e ao mar, sua grandiosidade e seu descolamento em relação ao bairro da Glória, pela pista de alta velocidade, permitem que ele seja classificado como um espaço de nível hierárquico municipal, tendendo à nacional. 
Relativamente ao tipo de espaço, o primeiro deve ser entendido como praça, enquanto o segundo pode ser classificado como uma esplanada. Cada um abriga diferentes usos e funções e, como espaços projetados, refletem isso pela visualidade. Ambos contemplam, de modo satisfatório, as funções para as quais foram concebidos.

A relação formal do primeiro espaço com o entorno construído ocorre por uma boa proporção, se tomados os parâmetros de análise de Yoshinobu Ashihara. Além disso, a vegetação de copas de altura média ou alta cria ambientações diversas, com trechos mais claros e abertos (praça e seu entorno imediato) e um trecho mais sombreado (da avenida Augusto Severo). Na esplanada do monumento, a relação formal apresenta predominância da dimensão horizontal, o que pode gerar certa dificuldade de apropriação por parte dos usuários (principalmente no caso de usuários de vizinhança, os quais, em geral, tendem a apropriar-se, de modo mais satisfatório, de espaços carregados de um caráter de aconchego ${ }^{18}$ ). A vegetação rareada contribui para um aspecto tendente à aridez. É, afinal, com a cidade que essa esplanada tem sua relação formal melhor realizada.

Os elementos e texturas dos materiais utilizados na praça Paris, que remetem a materiais tradicionais - pavimentação em saibro, trechos em vegetação forrageira, espelho d'água com jato central - garantem-lhe sensação de aconchego e proximidade, com a setorização entre áreas pela diferenciação entre texturas e materiais. Os edifícios do entorno, em sua maioria com estrutura em concreto armado e fachadas com pintura sobre alvenaria ou envidraçadas, seguem concepções e padrões formais de seus tempos de construção.

No monumento os materiais adotados seguem o padrão da modernidade arquitetônica, com superfícies lisas e pouco diferenciadas entre si, tanto em textura quanto em aparência: usou-se o granito liso (nos interiores), o granito flameado (no acabamento frontal da plataforma e revestimento do pórtico), o granilite de cor areia (no piso da plataforma), o cimentado (piso da esplanada no nível térreo e calçamento do entorno) e o mármore branco como revestimento das tumbas do subsolo. A estrutura da plataforma é de concreto armado. O alumínio que reveste as finas colunas do museu no térreo e o vidro temperado transparente, apesar de mostrarem presença quase neutra, reforçam a intenção voltada para matérias de textura lisa e de aspecto mais frio. $\bigcirc$ espelho d'água, escalonado em sentido descendente, do térreo ao subsolo, foi projetado dentro de formas e padrões modernistas. A neutralidade desses materiais tanto realça a plástica do monumento quanto destaca a presença das artes plásticas no conjunto. Os painéis e esculturas oferecem sempre contraste de cor e material em relação ao elemento construído. No entanto, mantêm-se naqueles as texturas frias e lisas: o azulejo brilhante nos painéis coloridos, o aço liso pintado em preto, o granito da escultura figurativa (ainda que flameado, sua aparência, a distância, é de homogeneidade). Essa presença das artes plásticas integra e ao mesmo tempo pontua, de modo contrastante, o espaço abstrato e contínuo. A espacialidade do conjunto é fluida, com pouca diferenciação entre áreas internas e externas. Pode-se detectar tanto uma certa influência do Pavilhão de Mies van der Rohe para o Pavilhão 
da Feira Internacional de Barcelona, em 1929, como a intenção do minimalismo (principalmente no subsolo, onde se localizam as tumbas) que será desenvolvido mais exaustivamente pelas artes plásticas nos anos 60 e 70, com Donald Judd, Sol LeWitt, Carl Andre e outros. A vegetação surge somente no entorno, e mesmo assim formada por gramíneas e árvores de presença pouco marcante (nas laterais do monumento essas surgem com maior presença em pontos que geram menor interferência na visualização geral do conjunto).

Por estar mais ligada ao bairro, a praça Paris conta com mais equipamentos e mobiliário urbano que o monumento. Embora ambos contem com guaritas de segurança, a praça possui, no entorno, um abrigo de ônibus municipal. Em seu interior há bancos em concreto, enquanto no monumento a amurada junto do mar faz o papel desse mobiliário urbano. Ressalte-se a incômoda presença de um respiradouro do metrô no interior da praça, impedindo o livre trânsito dos que ali praticam caminhadas ou corridas.

Por terem sido desenhados e executados segundo projetos de arquitetura, paisagismo e urbanização, os dois espaços contam com boa urbanização e infra-estrutura. A praça, cercada por gradeamento de aço, possui boa iluminação, a manter a ambiência do projeto original. As calçadas do entorno são pavimentadas (com saibro, junto da praça, e cimentado, na rua Augusto Severo) e demarcadas por meio-fio. A pista de rolagem para carros é em asfalto; a sinalização de trânsito é adequada; as canalizações de água e esgoto são, aparentemente, satisfatórias. $\bigcirc$ cabeamento elétrico é subterrâneo no entorno e no interior da praça. A guarita de vigilância citada acima garante segurança diurna e noturna à praça. Linhas de ônibus urbanos passam ali, onde se encontra um ponto de ônibus com abrigo. A estação da Glória do metrô situa-se próxima à praça. Há, também, na rua Augusto Severo, um ponto de táxi. $\bigcirc$ estacionamento nessa rua, proibido nos horários comerciais, é permitido à noite e nos finais de semana.

ambiente geral da praça Paris conta com grande insolação natural, mas as ruas de entorno têm forte sombreamento, o que define diferentes aspectos. A praça é relativamente aberta a ventos, ainda que protegida pelas árvores do entorno e um tanto afastada do mar. $\bigcirc$ ruído de veículos é maior nos horários comerciais, diminuindo nos outros períodos. No entanto, há ruídos durante as noites devido à presença de prostitutas e travestis que permanecem na avenida Augusto Severo. Desde as primeiras horas das manhãs dos sábados há, nessa rua, a presença de feirantes (de legumes, verduras, frutas, carnes e peixes) que trazem, além do barulho, maus cheiros e poluição visual e por detritos (ainda que, ao final da feira, a área seja lavada). Os bares ali existentes aumentam a emissão de ruídos com músicas tocadas em volumes que possibilitam, provavelmente, a audição por parte dos moradores dos andares mais baixos.

Monumento aos Pracinhas também conta com urbanização e infra-estrutura adequada. A iluminação valoriza sua arquitetura e paisagismo. As calçadas são pavimentadas com cimentado e meio-fio. A pista de rolagem de veículos e a ciclovia (junto do mar) são asfaltadas. A sinalização de trânsito é adequada; as canalizações de água e esgoto também são aparentemente satisfatórias; o cabeamento elétrico é subterrâneo. 
Membros das Forças Armadas garantem a segurança tanto na esplanada quanto em seu entorno, com guarita que controla também o acesso e permanência de veículos no estacionamento asfaltado e descoberto.

monumento e seu entorno têm grande insolação e são bastante abertos a ventos por sua localização junto da baía. A grande velocidade com que transitam os veículos gera ruídos os quais, sem serem incomodativos, contrastam com o ambiente geral de tranqüilidade. Os odores desagradáveis se concentram ao longo da amurada junto do mar, uma vez que mendigos e moradores de rua utilizam o trecho logo abaixo para suas necessidades fisiológicas.

\section{Hierarquias internas, permeabilidade, distribuição e padrões de uso dos espaços}

caráter particular dos espaços aqui analisados é também observado quanto à hierarquia interna aos próprios espaços e à permeabilidade. $\bigcirc$ predomínio de espaços públicos e semipúblicos, existente nesse conjunto formado pela praça Paris, a esplanada do monumento e as ruas de entorno, consiste em fato de exceção nos ambientes urbanos. A área do Monumento aos Pracinhas é, em sua maior parte, pública, com exceção das áreas do museu e da entrada para o mausoléu. $\bigcirc$ estacionamento, apesar de guardado por membros das Forças Armadas, tem área com trânsito livre para pedestres. Esses três trechos devem ser, portanto, considerados como semipúblicos. Da mesma forma, o gradeamento existente no contorno da praça Paris permite que esta seja fechada no final da noite, o que exige a classificação desse trecho como semipúblico. A presença de comércio no térreo dos edifícios da avenida Augusto Severo define uma predominância semipública para essa faixa mais adensada. A permeabilidade de quase toda a área é garantida, com exceção das portarias dos edifícios residenciais (espaços semiprivados) e dos trechos térreos ocupados por unidades residenciais nos edifícios multifamiliares (espaços privados).

Quanto aos tipos de uso, vê-se também, nessa área, o predomínio do bem público sobre os outros usos, o que facilitaria a apropriação por parte do usuário. No trecho adensado pelos edifícios predomina o uso misto, com edifícios residenciais cujos andares térreos abrigam instalações comerciais, especialmente bares, reforçando o caráter permeável e de fácil apropriação de todo o trecho. Além desses, outros edifícios têm seus usos voltados, exclusivamente, para instalações comerciais ou de serviço, enquanto um número ainda menor abriga, exclusivamente, unidades residenciais.

Os dois espaços, ainda que circundados por trechos de circulação de veículos e pedestres $^{19}$, correspondem a áreas de permanência. Observe-se que grande parte do trecho é composta por áreas verdes não-pisoteáveis, o que corresponderia a uma terceira categoria. Entre os espaços de permanência há dicotomias entre o trecho do Monumento aos Pracinhas, de caráter mais contemplativo, e o trecho da praça Paris, que convida à recreação infantil, às caminhadas e à corrida e, ao mesmo tempo, incorpora a função de espaço de contemplação. 


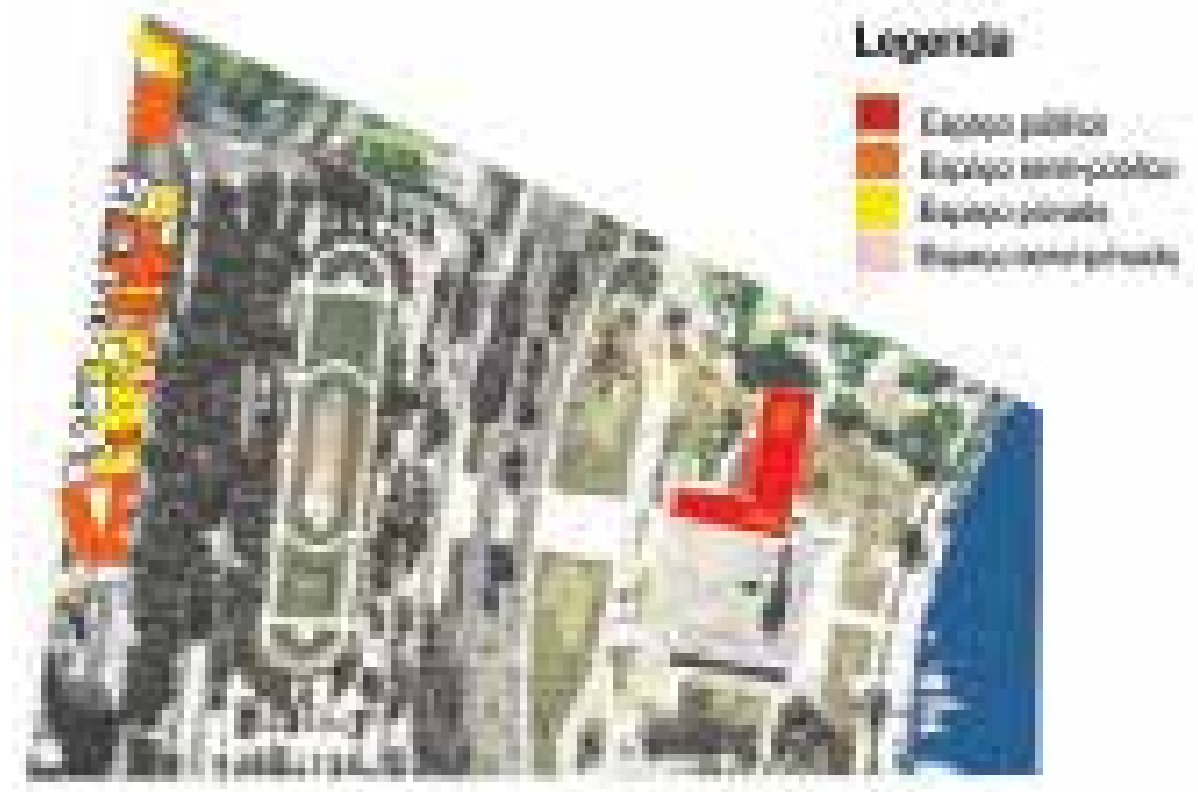

Figura 15: Mapa de permeabilidade, realizado a partir de trecho extraído do Mapa de Pontos Notáveis do Rio de Janeiro

Fonte: Instituto Municipal de Urbanismo Pereira Passos - Prefeitura da cidade do Rio de Janeiro, 1999

\section{Legenda}

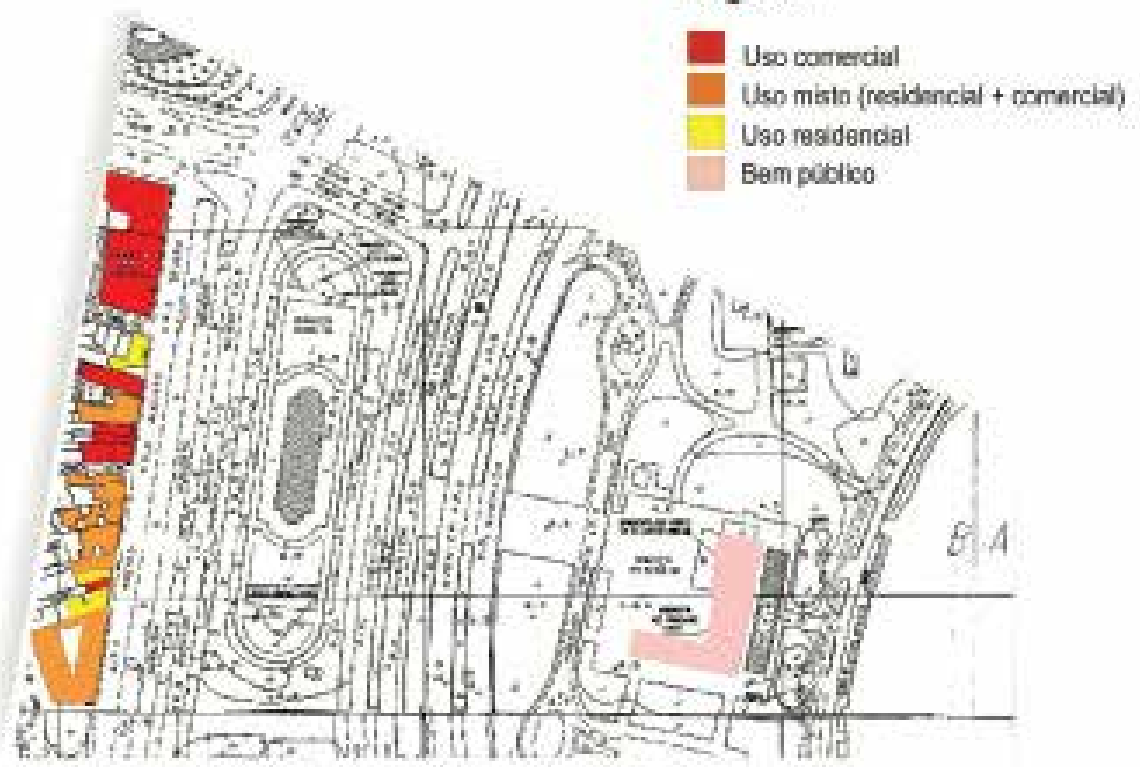

Figura 16: Mapa de permeabilidade, realizado a partir de trecho extraído do Mapa de Pontos Notáveis do Rio de Janeiro Fonte: Instituto Municipal de Urbanismo Pereira Passos - Prefeitura da cidade do Rio de Janeiro, 1999 


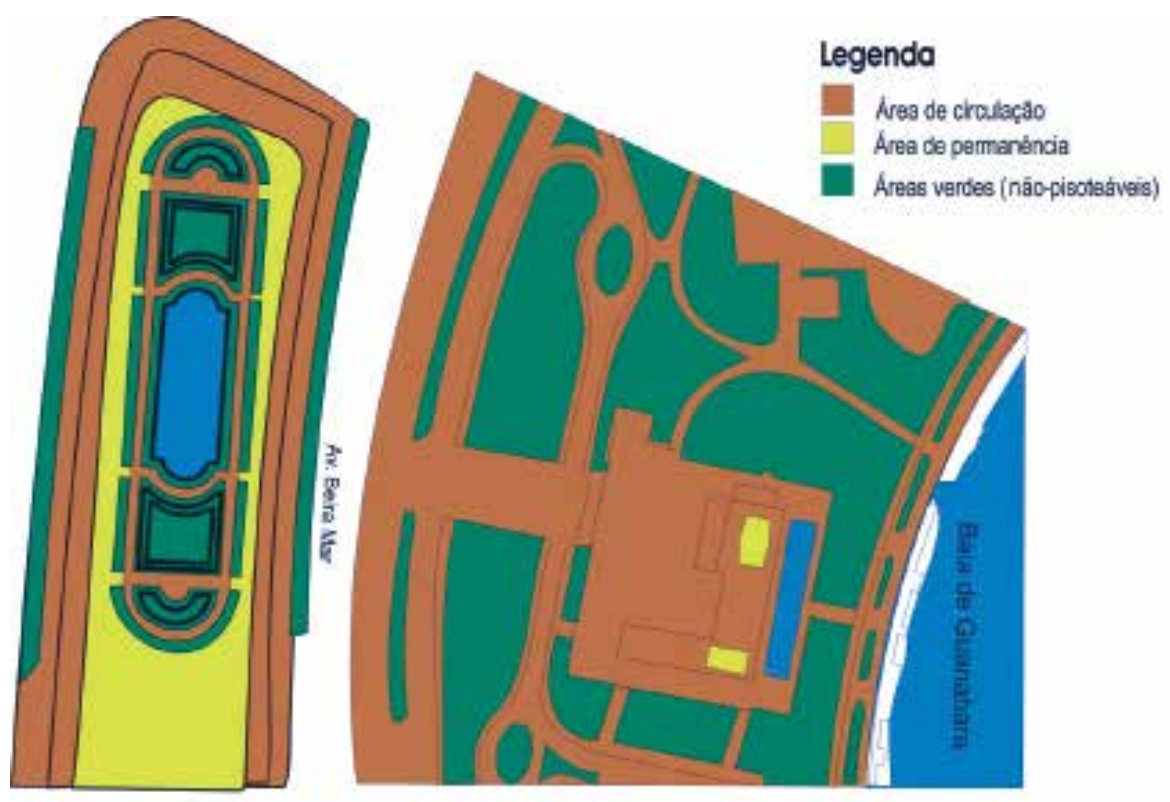

Figura 17: Mapa de distribuição dos espaços livres públicos, de circulação e permanência, realizado sobre Levantamento Aerofotogramétrico do Rio de Janeiro, fls. 287-B-III-5 e 287-D-I-2

Fonte: Instituto Municipal de Urbanismo Pereira Passos - Prefeitura da cidade do Rio de Janeiro, 1999

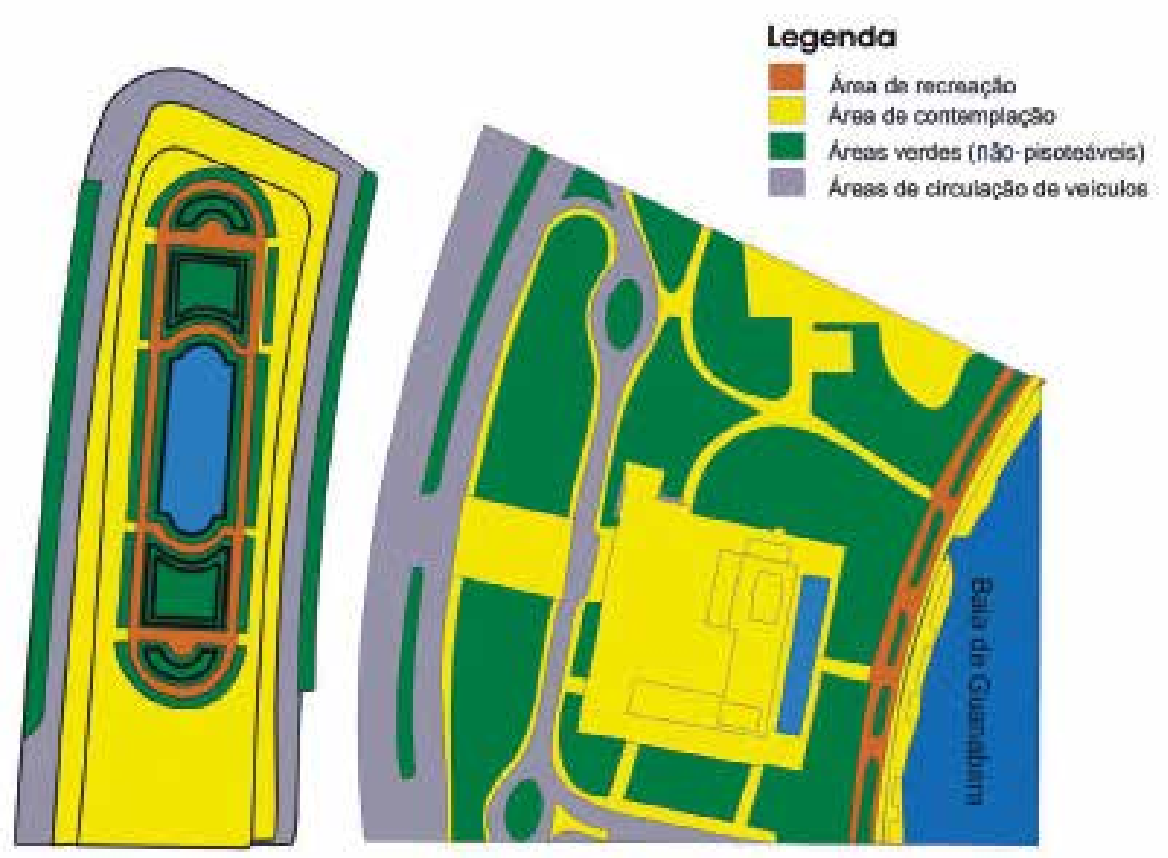

Figura 18: Mapa de contemplação e recreação, realizado sobre Levantamento Aerofotogramétrico do Rio de Janeiro, fls. 287-B-III-5 e 287-D-I-2

Fonte: Instituto Municipal de Urbanismo Pereira Passos - Prefeitura da cidade do Rio de Janeiro, 1999 


\section{CONCLUSÃO}

É interessante observar que esses dois importantes espaços livres públicos surgiram como acréscimos à geografia natural da cidade a partir de decisões políticas de caráter público ${ }^{20}$. Ambos carregam, de modo subjacente, a intenção de demonstração de poder e diferem, em naturalidade, dos lugares públicos surgidos quase espontaneamente nos interstícios da trama urbana.

Além dessa característica de acréscimo à geografia natural, deve-se lembrar que ambos os espaços foram gerados com obras viárias de grandes proporções. Nas duas situações observa-se relativa autonomia desses espaços públicos em relação aos setores habitacionais ou comerciais vizinhos. Se, na praça Paris, essa ruptura é tênue, no Monumento aos Pracinhas fica bem clara a distinção existente entre o bairro (inclua-se aí a praça Paris) e toda a faixa correspondente ao Aterro Glória-Flamengo. Talvez surja daí uma das explicações para o fato de, embora vizinhos a bairros populosos como a Glória e o Catete, esses dois espaços não se apresentarem, mesmo hoje, explorados e esgotados em todo o seu potencial. Ainda que criados especificamente como espaços públicos de recreação, contemplação e agregação de pessoas, as duas áreas analisadas incorporam, portanto, relações problemáticas quanto ao atendimento de suas funções previstas. Apesar de tudo isso, ou talvez devido à baixa freqüência de usuários na maior parte desse trecho (especialmente durante a noite), o que gera insegurança, esses espaços não contemplam, de modo satisfatório, seus papéis como espaços públicos. Acontece, certamente, a apropriação por parte do usuário, mas de forma problemática.

As fortes presenças formais de ambos os espaços definem-Ihes imagens que também podem thes criar dificuldade de apropriação por parte dos usuários. No caso da praça Paris, sua racionalidade de traçado e intenção de monumentalidade (apesar de suas reais proporções corresponderem às da escala humana) podem gerar certo distanciamento e mesmo "respeito": o sentimento é o de estar-se em um espaço a ser observado e contemplado, mas não a ser tocado, sentido e vivenciado. No Monumento aos Pracinhas, essa situação é muito mais problemática, visto que o espaço corresponde a um projeto arquitetônico moderno em uma área urbanizada dentro desses mesmos conceitos. A união desses dois fatores gerou inúmeros exemplos infelizes em todo o mundo; o exemplo do Monumento aos Pracinhas é apenas mais um indicador da dificuldade do Projeto Modernista para a solução de espaços de vivência urbana e comunitária. Chegou-se, assim, no monumento, a tal grau de abstração e racionalidade que a verdadeira apreensão desse espaço se torna plena apenas mediante certo esforço de apreensão: a naturalidade e despretensão necessárias aos espaços públicos Ihe faltam. Ainda que democraticamente aberto, o espaço não é inclusivo a qualquer atividade; na verdade, é o espaço que define seus próprios usos por meio de sua forma.

Ainda assim, não há dúvidas que tanto a praça Paris quanto o Monumento aos Mortos da Segunda Guerra Mundial sejam importantes espaços públicos cariocas, testemunhos de seus respectivos tempos e da trajetória do homem na busca por seus ideais. 


\section{Notas}

(1) $O$ trecho analisado da praça Paris corresponde àquele defronte à Esplanada do Monumento aos Pracinhas.

(2) Agache foi convidado pela administração Prado Júnior, em 1927, para um ciclo de palestras. Em 1928 realizou o plano urbanístico para o Rio de Janeiro, conhecido, hoje, como Plano Agache. Suas premissas de atuação ocorrem pelos aspectos de higienização, circulação e estética, com destaque para os espaços livres públicos.

(3) Esse desmonte foi iniciado em 1922, sob a administração Carlos Sampaio.

(4) A urbanização do Aterro Glória-Flamengo foi projetada por Affonso Eduardo Reidy, um dos mais renomados arquitetos modernistas brasileiros. $\bigcirc$ paisagismo ficou a cargo do mais importante paisagista brasileiro - Roberto Burle Marx.

(5) Instituído pela Comissão de Repatriamento dos Mortos do Cemitério de Pistóia.

(6) Adota-se, aqui, o entendimento que a primeira geração modernista foi a de Gregori Warchavchik, Lúcio Costa, Rino Levi e Flávio de Carvalho. A segunda geração seria a de Oscar Niemeyer, Jorge Machado Moreira e outros (SOUZA, p. 68).

(7) $\bigcirc$ movimento neocolonial encontrou grande repercussão na Exposição Internacional do Centenário da Independência, realizada no Rio de Janeiro em 1922.

(8) O Monumento aos Mortos da Segunda Guerra Mundial é também conhecido por esse nome.

(9) Segundo o dicionário Aurélio, morfologia é "tratado das formas que a matéria pode tomar".

(10) Apud Rossi, p. 64.

(11) Ver Solar Grandjean de Montigny. Affonso Eduardo Reidy (p. 112).

(12) O Guia da arquitetura art déco no Rio de Janeiro aponta, por exemplo, o Edifício Nathalia (avenida Augusto Severo, n. 264), e o Edifício Abreu (Rua Joaquim Silva, n. 3) como obras de 1936 e 1939, respectivamente.

(13) Um edifício de dois pavimentos à rua Joaquim Silva, n. 1 e outros no Beco das Carmelitas, n. 3, 5 e 7.

(14) Há, nesse trecho, a ocupação do subsolo, onde se desenvolvem áreas cobertas destinadas ao corpo da guarda e ao mausoléu, além de fonte d'água formada por plataformas escalonadas.

(15) Instituto Histórico e Geográfico Brasileiro, localizado na esquina da avenida Augusto Severo com rua Teixeira de Freitas.

(16) Em 1999, uma exposição de esculturas de vários artistas internacionais como Férnand Léger, Henry Moore e outros serviu para demonstrar o potencial turístico e cultural desse espaço.

(17) Já foram realizados, nessa esplanada, eventos de portes diversos, desde a celebração de uma missa pelo papa João Paulo I a reuniões de agremiações.

(18) São vários os aspectos que convergem para a formação de um juízo desse tipo por parte de uma comunidade, mas, certamente, os aspectos físicos são de grande influência no cômputo desses critérios.

(19) Entre a praça Paris e o bairro da Glória existe a avenida Augusto Severo; entre a esplanada do Monumento aos Pracinhas e a praça Paris há as avenidas Beira-mar e a Infante Don Henrique.

(20) Esse interesse por parte dos órgãos governamentais se deve, entre outros aspectos, ao fato de o Rio de Janeiro ter sido, até 1960, a Capital Federal, foco de interesse político em âmbito nacional e lugar para aonde se destinava considerável parte das verbas públicas.

\section{Bibliografia}

ASHIHARA, Yoshinobu. El diseño de espacios exteriores. Barcelona: Gustavo Gilli, 1982.

BRUAND, Yves. Arquitetura contemporânea no Brasil. São Paulo: Perspectiva, 1981.

CARVALHO, Anna Maria F. M. A talha do Mestre Valentim na lgreja de S. Pedro do Rio de Janeiro. Réquiem pela Igreja de S. Pedro: Um patrimônio perdido. Rio de Janeiro: Ministério da Cultura/Sphan/Fundação Casa de Rui Barbosa, 1987.

CZAJKOWSKI, Jorge (Org.). Guia da Arquitetura art déco no Rio de janeiro.

FERREIRA, Aurélio Buarque de Hollanda. Novo Dicionário da Língua Portuguesa. Rio de Janeiro: Nova Fronteira, 1986.

GUIA DA ARQUITETURA art déco no Rio de Janeiro. Centro de Arquitetura e Urbanismo do Rio de Janeiro. In: 
CZAJKOWSKI, Jorge. (Org.) Casa da palavra. Rio de Janeiro: Prefeitura da cidade do Rio de Janeiro, 2000.

LAMAS, José M. Ressano Garcia. Morfologia urbana e desenho da cidade. Lisboa: Fundação Calouste Gulbekian/ Fundação para a Ciência e Tecnologia, 2000.

MARX, Murilo. Cidade brasileira. São Paulo: Melhoramentos/Edusp, 1980.

MÓDULO. Módulo Revista de Arquitetura e Artes Plásticas, Rio de Janeiro, n. 6, p. 40-43, 1956.

PEVSNER, Nikolaus. Panorama da arquitetura ocidental. São Paulo: Martins Fontes, 1982.

ROSSI, Aldo. A arquitectura da cidade. Lisboa: Edições Cosmos, 1977.

SANTUCCI, Jane. A paisagem da área central e seu movimento de transformação na direção sul: $O$ papel do passeio público, da praça Paris e do Parque do Flamengo nessa trajetória. 2003. Dissertação (Mestrado) - PROARQ - UFRJ, Rio de Janeiro, 2003.

SOLAR GRANDJEAN DE MONTIGNY. Affonso Eduardo Reidy. Rio de Janeiro: PUC, 1985.

SOUZA, Abelardo de. A ENBA, antes e depois de 1930. In: XAVIER, Alberto (Org.). Depoimento de uma geração. São Paulo: Cosac\&Naify, 2003.

SUMMERSON, John. A linguagem clássica da arquitetura. São Paulo: Martins Fontes, 1982. 
Antônio Renato Guarino Lopes, Vera Regina Tângari 